\title{
RESENHA DA OBRA FORMAÇÃO DE PROFESSORES NO BRASIL: características e problemas
}

\section{REVIEW OF THE WORK TEACHER TRAINING IN BRAZIL: characteristics and problems}

Rosa Jussara Bonfim Silva ${ }^{1}$ https://doi.org/10.29327/216986.1.1-10

AKKARI, 2011. BARBOSA, 2011; Silva A 2002. Formação de professores no Brasil: características e problemas. Educação \& Sociedade. v. 31, n. 113, p. 1355-1379, 2010.

\section{A política educacional no contexto neoliberal e suas implicações na profissionalização docente da Educação Básica.}

A obra discute a questão da profissionalização docente diante da reconfiguração das políticas públicas educacionais sob a égide neoliberal. $O$ discurso ressalta que os problemas sociais, a precarização da escola, com destaque a falta de acesso e qualidade, só pode ser resolvida com a adoção de modelos educacionais estandardizados, numa avaliação, cujo ator é o Estado Avaliador. As novas posturas das políticas educacionais recaem principalmente sobre o docente, que muitas vezes encontra dificuldades de investir em sua formação e de ter seu trabalho reconhecido e também valorizado. A reconfiguração das políticas educacionais e o novo papel do Estado diante da educação.

Numa pesquisa realizada com alguns países sobre a valorização do professor comprovou que o Brasil, ocupou o penúltimo lugar, um resultado preocupante, que coloca em xeque o sistema educacional. A profissionalização docente, a necessidade do papel do professor, no campo da educação básica, surge como pedra

\footnotetext{
1 Doutora em Educação pela Universidade Católica de Brasília - UCB. Pedagoga, professora e Coordenadora do Curso de Pedagogia da Faculdade do Noroeste de Minas - FINOM. http://attes.cnpq.br/0517477118576942 https://orcid.org/0000-0002-2714-232X. E-mail: pedagogiaead@finom.edu.br
} 
angular das atuais políticas educacionais. Na década de 1990, aponta o neoliberalismo como uma solução para os problemas sociais, como a dificuldade de prover uma escola pública de qualidade e acessível a todos.

A relação público/privado surge como uma panaceia para os problemas educacionais, reconfigurando o papel do Estado, que passa de provedor da sociedade, para exercer seu novo papel de Estado-avaliador das políticas públicas educacionais para atender às demandas mercantis. Onde qualquer outro tipo de política, está alicerçada no exercício de poder na sociedade, seja na instância coletiva, ou na instância individual e, por meio dessa intervenção, constrói ou desqualifica de modo indireto visando a atingir determinada sociedade.

Independentemente do nível de ensino, esses questionamentos estão mais latentes, reconfigurando mais do que o aspecto administrativo, com a presença maior de instituições de ensino privadas, ou seja, aprender e ensinar faz parte do sistema econômico global. É parte do projeto de se criar um sistema econômico e educacional global harmonizado, como um serviço que pode ser comprado.

Há uma distorção do verdadeiro sentido da educação, em que, a formação para a cidadania emancipada, dá lugar a um investimento, que aposta na racionalização do Estado, na educação, na qualidade da educação expressa em números, principalmente na avaliação meritocrática. Para o trabalho docente, as consequências das alterações políticas na educação, apontam a necessidade de um profissional mais flexível, capaz de assumir vários papéis, precisa dar conta das exigências da sala de aula, além de assumir algumas tarefas ou funções administrativas, por força da descentralização escolar.

A globalização prega um modelo de avaliação, em que a qualidade social da educação é transformada em um enfoque produtivista, entre as instituições de ensino, públicas ou privadas. A lógica administrativa na escola prega uma eficiência baseada na lucratividade, que pese a necessidade de cortar gastos principalmente no que se refere à pesquisa e à extensão subjugando o trabalho docente e a necessidade de investir na formação deste profissional. 
Outros atores no campo educacional reforçam a necessidade de buscar medidas efetivas para lutar por uma educação contra hegemônica, para que, situações como a desvalorização docente, dê espaço para políticas públicas educacionais, primem pela qualidade da educação e pela dignidade da profissão docente.

A formação de professores para a educação básica no Brasil passa a ser realizada na educação superior como estabelecido na Lei 9.394/1996 de Diretrizes e Bases da Educação Nacional (LDB, BRASIL, 1996). Devido aos graves problemas em torno do processo de ensino-aprendizagem e qualidade da educação básica, tem-se intensificado a preocupação e discussão em torno dos cursos de licenciatura, estes são responsáveis pela formação inicial de professores. Mesmo elucidando a necessidade de formação de nível superior para os professores da educação básica, o caminho ainda é grande.

Em 2010, cerca de 50\% dos professores da educação infantil não tinham titulação de nível superior. Em relação aos professores da educação básica. A política educacional procurou oferecer aos futuros docentes uma formação mais científica e menos centrada em fórmulas prescritas. Assim, a escola também produz saberes essenciais na constituição da formação inicial e continuada dos professores. Porém, muitas vezes o conhecimento produzido pela universidade não faz sentido na escola e o conhecimento produzido na escola não é valorizado pela universidade.

A obra mostra a respeito da formação de professores que na atualidade as condições dos cursos de formação de professores para a educação básica necessitam de reestruturação, pois falta um eixo formativo para a docência, o que acaba acarretando uma formação frágil, distante das necessidades exigidas pela Educação Básica.

A formação de professores é clara. É o setor privado responsável pela formação de 78,5\% das matrículas em cursos de graduação presenciais no Brasil, a maior parte em instituições não universitárias e em cursos noturnos. Essas instituições têm demonstrado situações precárias para a oferta dos cursos, a formação de professores, no Brasil, se dá em grande parte em instituições privadas. 
Portanto, a formação de professores para a educação básica deve partir da prática e agregar, conhecimentos que vão além do pedagógico, que partam do princípio da educação cidadã. Há alguns importantes aspectos na formação como a polivalência e a especificidade, como a participação e a individualização, a liderança e a cooperação, a abstração e as práticas concretas, todos esses conhecimentos, resultam em uma maneira nova de entender a educação.

\section{Profissionalização docente: o discurso e a prática}

A docência é resultado de um processo histórico carregada de elementos de natureza liberal do profissionalismo e elementos do ideário religioso da vocação. Observa-se a precarização da docência por meio do aviltamento salarial e precariedade das condições do trabalho, o que muitas vezes justifica o desinteresse dos jovens pela profissão. Os baixos salários dos professores têm contribuído para a não atratividade da careira, isto se dá pelas condições de formação oferecidas quanto pelas condições de exercício da profissão docente.

Há, portanto cinco estágios que caracterizam o desenvolvimento das profissões mais estruturadas ocupação em tempo integral; de uma agência de formação, que prepara o profissional para uma ocupação específica; fundação de uma associação profissional; agitação desenvolvida pela associação com a finalidade de encaminhar as reivindicações e interesses dos profissionais, e adoção de um código formal para a profissão.

Em países que o mercado exerce grande influência sobre a profissão. As teses que defendem que qualquer um pode ser professor e ser formado em qualquer instituição estão seguindo a linha de destruição da profissão. Um estudo recém publicado acerca dos salários dos professores brasileiros e implicações para o trabalho docente constatou que os salários dos professores brasileiros são baixos, se comparados aos de outras profissões com a mesma exigência de formação.

$\mathrm{O}$ estudo mostrou que os baixos salários provocam implicações, sobre a profissão docente quanto sobre o professor. 
Essas implicações seriam o baixo interesse na carreira e a dificuldade de reter bons professores. As implicações sobre o professor como se referem à redução do seu poder aquisitivo o sentimento de insatisfação e de desânimo por pertencer uma profissão pouco valorizada. A intensa jornada de trabalho e a precarização dos professores para minimizar os dados dos baixos salários sobre a profissão o professor dificultam o reconhecimento do trabalho docente como uma profissão bem estruturada.

A pesquisa ocorreu em uma Universidade Pública Estadual, que fica localizada no Estado de Minas Gerais, e os cursos foram os de licenciatura. Apesar dos dados encontrarem em fase de análise, eles já apontam problemas referentes intensificação, à precarização e profissionalização do trabalho docente.

\section{Algumas considerações}

Vimos que a ideia de uma educação de qualidade, está atrelada às demandas mercantis e busca atender a um modelo de educação imposto por atores internacionais, que, com o discurso de buscar o desenvolvimento econômico e tecnológico do País, racionalizam cada vez mais o papel do Estado e comprometem o verdadeiro sentido da educação, que deveria voltar se para a formação de cidadãos críticos e emancipados.

$\mathrm{Na}$ berlinda dessa nova ordem vigente, especialmente no campo da Educação Básica, estão os docentes, que buscam constantemente um reconhecimento do seu trabalho e uma definição clara da sua função. Conhecer o professor, identificar seu perfil social, cultural e econômico é essencial para ajudar na estruturação de políticas que promovam a formação de professores para a educação básica, de forma que tornem a profissão docente mais atrativa e valorizada e que propicie uma educação com qualidade.

$O$ processo de valorização do profissional da educação perpassa pela formação e pelo processo de profissionalização, o que evidencia a necessidade de uma sólida formação teórica, em que os futuros professores passem a conhecer as matrizes do conhecimento 
e produzi-las. Isso será possível apenas em cursos que assumam a licenciatura como projeto específico do curso. 